\title{
THE DISTRIBUTION, ECOLOGY AND MANAGEMENT OF TWO RARE TASMANIAN SEDGES - SCHOENUS ABSCONDITUS KUK. AND CAREX TASMANICA KUK.
}

\author{
by Louise Gilfedder and J.B. Kirkpatrick
}

(with five tables and two text-figures)

Gilfedder, L. \& Kirkpatrick, J.B., 1996 (30:vi): The distribution, ecology and management of two rare Tasmanian sedges - Schoenus absconditus Kuk. and Carex tasmanica Kuk. Pap. Proc. R. Soc. Tasm. 130(1): 31-40. https://doi.org/10.26749/rstpp.130.1.31 ISSN 0080-4703. Department of Geography and Environmental Studies, University ofTasmania, GPO Box 252C, Hobart, Tasmania, Australia 7001 QBK and formerly LG), LG now Parks and Wildlife Service, GPO Box 44A, Hobart, Tasmania, Ausrralia 7001 (LG).

The sedges, Carex tasmanica and Schoenus absconditus, were considered to be threatened species at the national level. They are species of grassland and grassy woodland in the driest parts of Tasmania, C. tasmanica being associated with drainage lines, and $S$. absconditus characteristically occurring in Themeda triandra grassland, in situations where there is a large amount of intertussock space. Both species proved much more common than previously thought, and both species have been downlisted. They are both well-adapted to mechanical disturbance and sheep grazing. C. tasmanica is also herbicide resistant. However, mowing and catcle grazing deleteriously affect C. tasmanica. S. absconditus can no longer be regarded as a rare or threarened species. However, C. tasmanica has disappeared from two localities out of 30 in the past four years and has no substantial populations in any secure reserve. Secure reservation is needed for this vulnerable species.

Key Words: Carex tasmanica, conservation, disturbance, grazing, management, Schoenus absconditus.

\section{INTRODUCTION}

The maintenance of native biological diversity is now a major national policy goal in Australia. If the species level of native biological diversity is to be maintained, rare and threatened taxa need particular attention, as these are most likely to become extinct in the near future. National listings of rare and threatened vascular plant species have been available for Australia for some time (e.g. Briggs \& Leigh 1988). These have been based on information on current distributions and population sizes that is often very partial, especially in the cases of sedges (Cyperaceae), rushes (Juncaceae) and grasses (Poaceae), which tend not to be favoured by collectors and which often present identification difficulties. There is a need to gain data on the distribution and ecology of listed species, in order to confirm or reject their listed status and to develop, if necessary, programs for their recovery. In this paper we report such investigations into the distribution, ecology and management of two Tasmanian sedges, Carex tasmanica and Schoenus absconditus.

Carex tasmanica is a tufted rhizomatous perennial sedge with discinctive coiling of the distal portion of the etect leaves (Curtis \& Morris 1994). The leaves may be flat, broad or inrolled, and may be up to $0.4 \mathrm{~m}$ long. $S$. absconditus is also a tufted thizomatous perennial sedge which is distinguished by a very short culm bearing the inflorescence (Curtis \& Morris 1994).

Schoenus absconditus was recorded on the national listing as a vulnerable Tasmanian endemic species with a distribution of less than $100 \mathrm{~km}^{2}$ (Briggs \& Leigh 1988). C. tasmanica was originally more widespread in its distribution, occurring in eastern Tasmania and in western Victoria, where it is now considered a vulnerable species (Gullan et al. 1990). It is also reported as occurring on the Darling Downs of Queensland (Hnatiuk 1990) — although there are no records at the Queensland Herbarium (R. Fensham, pers. comm.). The species has been listed as nationally endangered (Briggs \& Leigh 1988) but was not included in the recent national list (Endangered Flora Network 1993), nor listed at the state level by the Flora Advisory Committee (1994).

\section{METHODS}

The fotmer and extant distributions of Carex tasmanica and Schoenus absconditus were determined from herbarium collections, literature references and survey data. Searches were made at these sites and environmentally similar ones. Where either species was located, floristic and site data were recorded. Quadrats measuring 1 x $10 \mathrm{~m}$ were subjectively placed in the least disturbed vegetation in which $C$. tasmanica or $S$. absconditus occurred. Presences were recorded for all vascular plant species. Species nomenclature follows Buchanan (1995).

Altitude, surface geology, soil type and surface soil $\mathrm{pH}$ (using a CSIRO soil-testing kit) were measured or noted in the field. The slope and aspect of each site were determined, using a clinometer and compass respectively. Climatic data were derived for each site using the Bioclimatic Prediction System (Busby 1988).

The polythetic divisive technique TWINSPAN (twoway indicator species analysis) (Hill 1979) was used to obtain sorted tables for quadrats with each species. These were re-sorted manually and used as the basis for the selection of communities.

The percentage frequencies of species in the quadrats with $S$. absconditus and those with $C$. tasmanica were calculated, as were the percentage frequencies of all species in a grassland and grassy woodland database, consisting of 1206 quadrats. A list was made of those species that occurred in $10 \%$ or more of quadrats in any of the databases, the list being separated into those occurring more frequently with S. absconditus, those occurring more frequently without S. absconditus, those occurring more frequently with C. tasmanica and those occurring more frequently without C. tasmanica. These species were then classified into lifeform 
groups (shrub or tree; grass or graminoid; herb; geophyte) and two origin groups (Tasmanian native; other).

The response of $S$. absconditus to different management regimes was documented by placing transect lines through vegetation under different management containing the species and determining their density. S. absconditus plots were established in ungrazed, lightly grazed, heavily grazed situations, and on revegetating gravel pits. The former two situations were at Tunbridge, while the latter two were at Nile. For $C$. tasmanica transects were placed in vegetation at the Queens Domain that was either regularly mown, burned then sprayed with a broadleaf selective herbicide or mulched with woodchips. These transects were monitored from 1991-95 to determine the effect of site management on numbers of $C$. tasmanica. Kruskal-Wallis One-way Analysis of Variance by Ranks and the Mann-Whitney U Test (Siegel 1956) were used to determine if the densities of S. absconditus and C. tasmanica significantly varied under different management regimes, over time, and in relation to various ground covers.

\section{RESULTS AND DISCUSSION}

\section{Distribution, Environment and Phytosociology of Carex tasmanica}

Carex tasmanica was recorded at 27 locations in northern, eastern and southern Tasmania, and the Midlands (fig. 1). It occurs from sea level to approximately $600 \mathrm{~m}$ on a wide range of soil types derived from dolerite, basalt, sandstone and wind-blown sands. The $\mathrm{pH}$ of these soils varies from

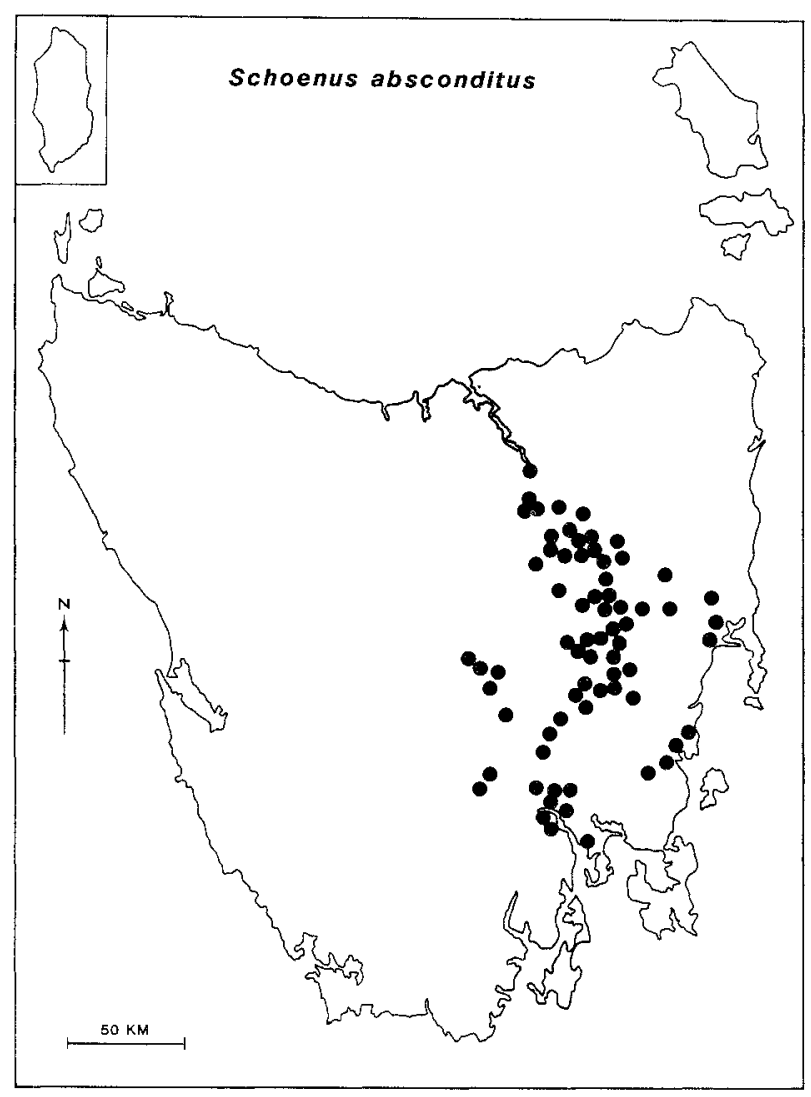

FIG. I Distribution of Schoenus absconditus. weakly acid to weakly alkaline, with a median value of 7.0. Mean annual precipitation varies from approximately 550 $\mathrm{mm}$ to approximately $700 \mathrm{~mm}$, with a median value of 656 $\mathrm{mm}$. Mean precipitation in the driest monrh varies from approximately $35 \mathrm{~mm}$ to $75 \mathrm{~mm}$ with a median of $65 \mathrm{~mm}$. The mean temperature of the warmest month varies from $12.3^{\circ}$ to $16.3^{\circ} \mathrm{C}$ with a median value of $15.5^{\circ} \mathrm{C}$, and that of the coldest from $4.5^{\circ}$ to $8.6^{\circ} \mathrm{C}$ with a median of $7.0^{\circ} \mathrm{C}$.

All of the populations are associated with constantly moist places, such as seepage or drainage lines. Tree cover is rare, but the species does occur in woodland and forest communities dominated by Eucalyptus ovata. Most of the populations occur in a matrix dominated by exotic species. The percentage of exotic species in quadrats varied from 25 to 90 with a mean of 51 . Carex gunniana, Juncus spp., native Poa spp. and Acaena novae-zelandiae were the only native taxa to occur in more than $40 \%$ of the quadrats with C. tasmanica. The exotic species found in more than $40 \%$ of the quadrats were Holcus lanatus, Plantago lanceolata, Hypochoeris radicata, Leontodon taraxacoides and Agrostis capillaris.

The native species that were more abundant with C. tasmanica than in the grasslands and grassy woodlands database as a whole were mostly taxa characteristic of the margins of wetlands, including Leptospermum lanigerum, Poa labillardierei, Carex gunniana, Eleocharis acuta, Juncus australis and J. pauciflorus. Thirty of the 43 species that were more abundant with $C$. tasmanica than in the larger dataset were exotics, mostly herbs and perennial grasses (table 1). In contrast, only five of the 73 species that were more abundant in the larger dataset were exotics (table 1).

The high and variable degree of invasion by exotics makes it difficult to perceive strong communities within the sorted table (table 2). However, the left half of the matrix can be distinguished from the right half on the basis of the relatively high constancy and fidelity of the native species: Asperula conferta, Geranium solanderi, Veronica gracilis, Poa labillardierei and Acaena novae-zelandiae. The right half of the matrix is less strongly distinguished by the relatively high constancy and fidelity of the native species: Carex gunniana, Themeda triandra, Hypericum gramineum and Juncus pauciflorus. The former community tends to be associated with sedimentary rocks and streamsides in the inland locations, while the latter tends to occur preferentially on igneous rocks and soaks near the coast.

\section{Distribution, Environment and Phytosociology of Schoenus absconditus}

Schoenus absconditus was found at more than 70 localities (fig. 2). It has been previously misidentified as the more common S. apogon. It occurs in southeastern and eastern Tasmania, being recorded as far north as Launceston. It occurs on soils ranging in texture from sandy loams to clay loams and clays derived from basalt, dolerite, sandstone, mudstone, alluvium and Holocene deposits. These soils vary in surface $\mathrm{pH}$ from 6.0 to 9.0 with a median value of 6.5. It ranges in alcitude from sea level to $650 \mathrm{~m}$. Mean annual rainfall varies from 450 to $900 \mathrm{~mm}$ wich a median of $605 \mathrm{~mm}$, with the rainfall in the driest month varying from $20 \mathrm{~mm}$ to over $70 \mathrm{~mm}$ with a median of $60 \mathrm{~mm}$. The mean temperature of the warmest month varies from $12.6^{\circ}$ to $16.3^{\circ} \mathrm{C}$ with a median of $15.6^{\circ} \mathrm{C}$, and that of the coolest month varies from $4.6^{\circ}$ to $8.5^{\circ} \mathrm{C}$ with a median of $6.5^{\circ} \mathrm{C}$. 
TABLE 1

Composition of lifeform groups associated with Carex tasmanica or Schoenus absconditus*

\begin{tabular}{lccccc}
\hline Lifeform group & \multicolumn{2}{c}{$\begin{array}{c}\text { More common with Carex } \\
\text { Observed }\end{array}$} & Expected & \multicolumn{2}{c}{$\begin{array}{c}\text { Less common with Carex } \\
\text { Observed }\end{array}$} \\
\hline Trees and Shrubs & 5 & 6 & 10 & 9 \\
Grasses and graminoids & 15 & 16 & 28 & 29 \\
Herbs & 23 & 20 & 31 & 34 \\
Geophytes & 0 & 1 & 4 & 3 \\
Total & 43 & 43 & 73 & 73 \\
& More common with Schoenus & Less common with Schoenus \\
Lifeform group & Observed & Expected & Observed & Expected \\
& 2 & 6 & 9 & 5 \\
Trees and Shrubs & 14 & 19 & 23 & 18 \\
Grasses and graminoids & 37 & 30 & 22 & 29 \\
Herbs & 5 & 3 & 1 & 3 \\
Geophytes & 58 & 58 & 55 & 55 \\
Total & & & & \\
\hline
\end{tabular}

* The number of species in different lifeform groups that are more frequent in vegetation with either Carex tasmanica or Schoenus absconditus than in Tasmanian grasslands and grassy woodlands and vice-versa. Only species occurring in more than $20 \%$ of the quadrats in at least one of the data sets are included.

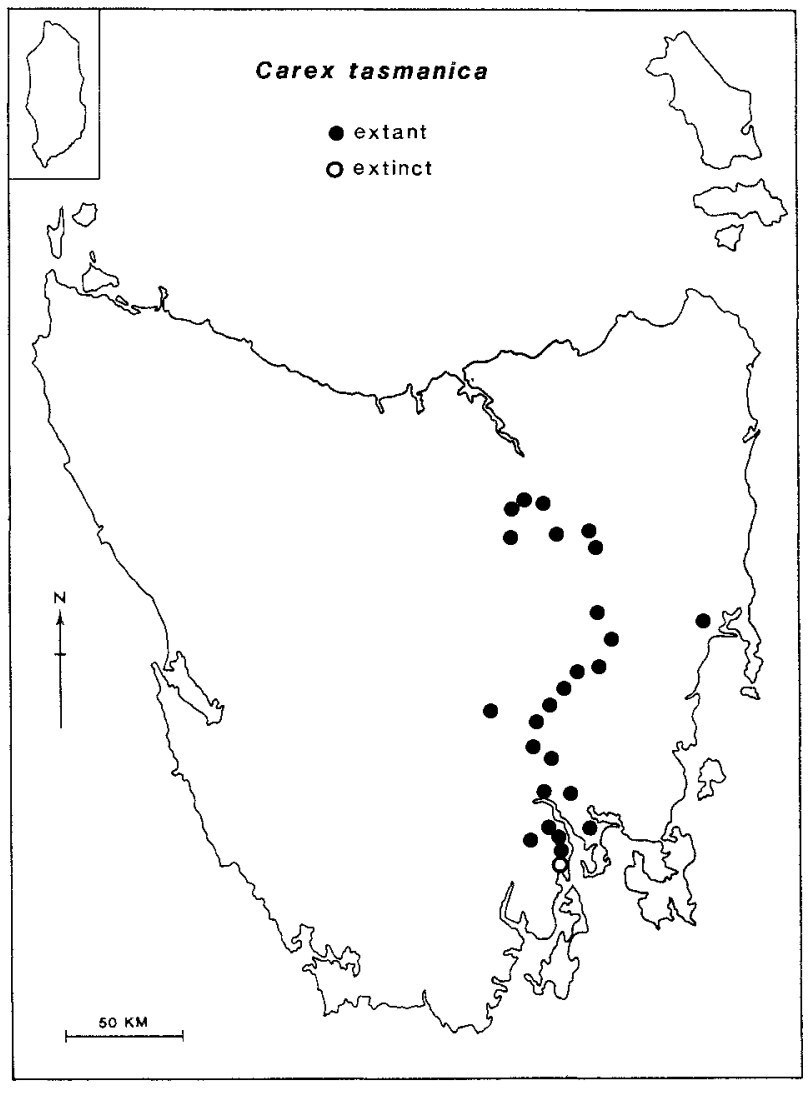

FIG. 2 - Distribution of Carex tasmanica.
Schoenus absconditus occurs in grasslands and grassy woodlands on well-drained sites in which the ground stratum is dominated by kangaroo grass (Themeda triandra), wallaby grass (Danthonia spp.), tussock grass (Poa spp.) and a rich variety of herbs. Eucalyptus pauciflora and $E$. ovata are the most common dominants in woodland with $S$ absconditus. Native species tend to dominate the cover and richness of the quadrats. The percentage of exotic species in quadrats varied from zero to 60 , with a mean of 22.

The native taxa that occurred in more than $40 \%$ of the quadrats with $S$. absconditus were Themeda triandra, Danthonia spp., native Poa spp., Leptorhynchos squamatus, Oxalis perennans, Carex breviculmis, Geranium solanderi, Plantago varia, Ehrharta stipoides and Pimelea humilis. Only three exotics were as frequent. These were Aira caryophyllea, Centaurium erythraea and Leontodon taraxacoides. The native species that occurred in more than $10 \%$ of the quadrats with $S$. absconditus and had a higher percentage frequency in these than in the grasslands and grassy woodlands data set were mainly perennial herbs. More herbs and geophytes than expected occurred preferentially with $S$. absconditus (table 1). The converse was true for grasses and graminoids, and for shrubs and trees. Eighteen of the 58 species that occurred preferentially with $S$. absconditus were exotics, largely grasses and herbs. Of those 55 species that occurred preferentially in the data set as a whole, only four were exotics.

The sorted table (table 3 ) is again somewhat diffuse. However, the quadrats divide into two approximately equal sets, one of which is characterised by the following native plants: Chrysocephalum apiculatum, Geranium solanderi, Danthonia tenuior, Vittadinia muelleri, Scleranthus diander, Convolvulus erubescens, Ptilotus spathulatus and Pimelea humilis. The other is characterised by the following native species: Gnaphalium collinum, Hypericum gramineum, Ehrharta stipoides and Drosera peltata. 


\section{TABLE 2}

\section{Sorted table for quadrats with Carex tasmanica}

Lomandra longifolia * Acetosella vulgaris *Aphanes arvensis * Trifolium pratense * Poa pratensis Hypoxis glabella *Bromus mollis * Briza minor Mazus pumilio *Bromus diandrus *Rumex crispus * Phalaris spp. * Carduus nutans Ehrharta stipoides *Lolium perenne Elymus scabrus Carex gaudichaudiana *Trifolium glomeratum Juncus bufonius +Schoenus absconditus Asperula conferta Geranium solanderi *Myosotis discolor Veronica gracilis *Cirsium vulgare *Bellis perennis *Trifolium aubium * Taraxacum officinale Poa labillardierei *Aira caryophyllea Acaena novae-zelandiae *Prunella vulgaris Juncus australis * Plantago coronopus Epilobium billardierianum Carex breviculmis Calocephalus lacteus Juncus subsecundus *Trifolium repen Acaena agnipila Leptorynchos squamatus oxalis perennans *Hypochoeris radicata -1-111----1--1
$1223112112123433333 \quad 123112331222$ 5145275036569004678979469302142831312788

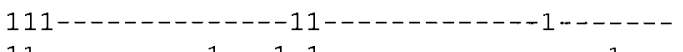

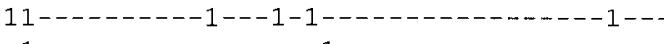

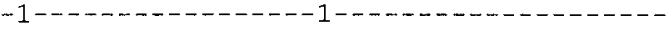

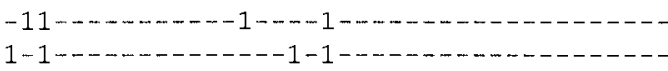

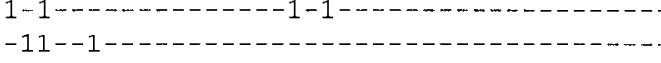
$-1-1+\cdots$ $--1--1$

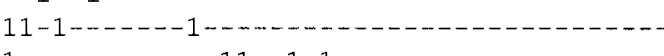

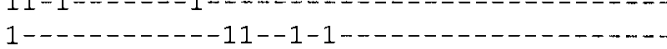

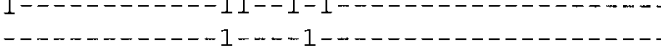
$----------1---1-1$ -1--1--- - - 1-1-11-11-11-1--1--11---.-$----1----11$ - - - 1-- - 1-1---

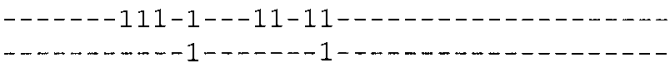
- $1-111-1-11-1$ $1-11-111111-1-111--1-\cdots+-1-0-0-1$ -1---1-111-111----1-_--_-n-1-1-1-111-11-11111---111-1-111111--1--1-- - -

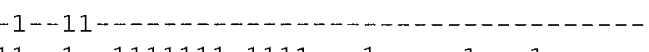
11--1--1111111-1111---1----1---1-- $-1-\cdots-11-11-\ldots$ -1-111-1-1111-1----11---------11-1-

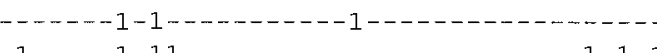

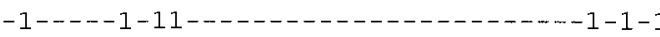
-

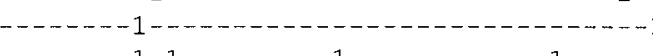
$1-1-1$

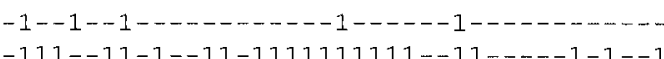
$-111--11-1--11-1111111111-111--1-1-1$
Oreomyrrhis eriopoda *Anthoxanthum odoratum Danthonia carphoides

*Trifolium subterraneum *Vicia sativa

*Cirsium arvense

*Cynosurus cristatus Carex tasmanica

Juncus spp.

*Holcus lanatus

* Plantago lanceolata

Danthonia spp.

Acaena echinata

*Leontodon taraxacoides

Eleocharis acuta

Leptospermum lanigerum

Hypericum gramineum

Carex gunniana

${ }^{\star}$ Rosa rubiginosa

*Potentilla spp.

* Sonchus asper

*Anagallis arvensis

*Ulex europaeus

* Dactylis glomerata

*Agrostis capillaris

Themeda triandra

Schoenus apogon

*Centaurium erythraea

*Tragopogon porrifolius

* Picris hieracioides

plantago varia

Danthonia caespitosa

Danthonia laevis

* Juncus articulatus

*Dipsacus fullonum

Dichondra repens

*Rubus fruticosus

Poranthera microphylla

* Urospermum dalechampi

* Avena fatua

* Crataegus monogyna

Juncus pauciflorus

Eleocharis sphacelata

*Foeniculum vulgare

Ajuga australis

Danthonia racemosa

*Sonchus oleraceus

* Lolium rigidum

*Lotus corniculatus $\begin{array}{llllll}1223112112 & 123433333 & 123 & 1 & 12331222\end{array}$ 5145275036569004678979469302142831312788 1-1-1-1--- - - - 1 1111111111111111111111111111111111111111 1-111--1111111111--.-1111111-1111-1-1111 1-1-11-111111--1111-11111111111111-11111 1---1111--1111-11-1-111111111-1111111111 $-1--11---1-1-----1--1111-11---\cdots--1$ --1-1--1-111111----11111---11--111----1

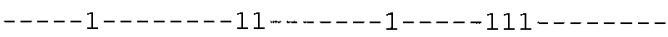
- -----111-11-----11-111-1----111-1-1-- - 1 - $-01-1-0 .-0-1-1-1-1$ ---1---1-11--11-1--11111---o--1111111$-11---1-1$ $--1-11--1--\ldots-\ldots-1-11111-1----1-\ldots$

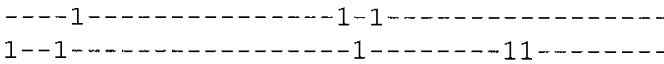

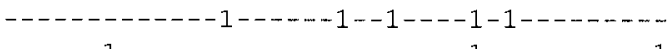
$-0-1-0-1-1$ - $1-0-1--1-0-11-1--11-0-1$ -

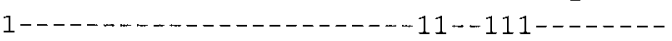
1$-1,-11-\cdots-1-1$ - - …… - 
Additional species

15: *Cerastium glomeratum, *Phalaris canariensis 21: Colobanthus curtiseae, Crassula sieberiana, Chrysocephalum apiculatum, *Erophila verna, Hovea linearis, *Parentucellia viscosa, Pimelea humilis, Scleranthus biflorus

24: Bolboschoenus caldwellii, cotula australis, Glyceria australis, Hypoxis hygrometrica,

Ranunculus decurvus, Senecio hispidulus.

Villarsia reniformis

35: *Erodium cicutarium, *Lepidium africa hnum, * Poa bulbosa

12: Rumex dumosus, Solenogyne gunnii

17: Acaena ovina, Danthonia semiannularis,

Drosera peltata, plantago antarctica

25: *Briza maxima, *Eragrostis sp., *Trifolium

fragiferum

\section{* = introduced species \\ $+=$ endemic species}

\author{
13: Carex appressa, Carex inversa \\ 26: Drosera pygmaea \\ 16: *Plantago major \\ 29: Dichelachne rara, Hydrocotyle \\ sibthorpioides \\ 30: Epilobium hirtigerum \\ 40: *Lysimachia nummularia \\ 34: *Potentilla spp., *Rumex pulcher \\ 36: *apsella bursa-pastoris, Plantago paradoxa \\ 37: * Cynosurus echinatus \\ 38: *Achillea spo., Hemarthria uncinata \\ 39: *Moenchia erecta, *Ranunculus repens \\ 7: *inum trigynum \\ 9: Astroloma humifusum, Eucalyptus ovata, \\ Geranium potentilloides, Juncus planifolius, \\ Linum marginale \\ 4: *Erica Iusitanica, Eriochilus cucullatus, \\ Eucalyptus globulus, Leptospermum scoparium, \\ * Leucanthemum vulgare \\ 6: Stipa spp. \\ 19: Baumea acuta, Isolepis platycarpus \\ 14: Danthon gia penicillata \\ 23: * Salix alba, Gonocarpus tetragynus \\ 22: Rumex brownit \\ 28: *uncus capitatus, *Paspalum dilatatum \\ 8: Carex iynx, Centipeda minima, Cotula \\ reptans, Geranium sessiliflorum, Hypericum \\ japonicum, plantago daltoni
}

Mowing appeared to preclude such establishment (table 5). The three treatments resulted in no statistically significant changes in percentage cover, number of clumps or number of individuals over the four-year period. There was an unsurprising significant increase in grass, exotic herb and exotic rosette cover in the four years after the burning and herbiciding treatment, but the levels of cover were not as great as those resulting from the mowing treatment. Exotic grass cover also significantly increased over the four years in the woodchip mulch and mown treatments (table 5).

\section{Conservation and Management}

We located many previously unknown populations of both C. tasmanica and S. absconditus between 1991 and 1995 . S. absconditus proved to be extremely common in native pastures. It is found in two secure reserves (Township Lagoon Nature Reserve and Tom Gibson Nature Reserve), and in several less secure reserves, such as the Meehan Range State Recreation Area and the Queens Domain in Hobart. This security, its large number of known populations and its ability to persist with current land use, short of cultivation, has resulted in its removal from the nation al listing of threatened species (Endangered Flora Network 1993) and the Tasmanian state listing (Flora Advisory Committee 1994).

The majority of the populations of $C$. tasmanica are on either private land or on road or rail reserves. It occurs in a number of council reserves, such as the Queens Domain in Hobart. Two individuals were recorded from a picnic area at Myrtle Gully within the Mount Wellington Park, which has secure status. Another slightly larger population occurs within the less secure Lake Dulverton Wildlife Sanctuary.

Although many new populations of $C$. tasmanica have been found, its future is not considered secure. Virtually all populations are found on private land or roadside verges,
Pine bark mulching was the most successful of the treatments for the establishment of new germinates (table 5). low levels (table 4).

Carex tasmanica also occurs as sites where herbicide has been used to control roadside vegetation. Where most pecies have died, it maintains its health.

The latter community occurs in areas of higher available
moisture than the former, which is the characteristic (mean $=169$, standard error $=23$ ) and heavily gazed (mean $=188$, standard error $=39)$ native pastures indicate a result of competition reduction (cf. Gilfedder \& significantly with either grass cover, being highest at medium levels; bare ground, being highest at medium levels and absent where bare ground is absent; rock cover, being greatest at high and low levels; or litter, being highest at 
TABLE 3

Sorted table for quadrats with schoenus absconditus

$2678193478 \quad 125545555554444455334 \quad 233334113389936788999679126679112866667780677801122228912478$ 3806166267602879802345893467916015134278357802424147904453589113617395650235628304572178047990915198

Hypoxis hygrometrica * Romulea longifolia * Silene gallica

*VeIlereophyton dealbatum Stipa semibarbata Bulbine bulbosa Hakea microcarpa Brachyscome graminea

Linum marginale Dichelachne crinita

Stipa scabra Stipa stuposa Chrysocephalum apiculatum Leucochrysum albicans Vittadinia cuneata Bossiaea riparia Danthonia tenuior Vittadinnia muelieri scleranthus diander Dianella Iongifolia Brachyscome rigidula * Cynosurus echinatus *Vulpia bromoides Velleia paradoxa + Stackhousia gunnii * Poa bulbosa Craspedia Tunbridge *Erodium moschacum * Tragopogon porrifolius *Vicia sativa *Trifolium subterraneum Calocephalus lacteus * Plantago lanceolata * Sonchus asper *Cirsium arvense Acaena agnipila * Bromus diandrus * Holcus lanatus *Bellis perennis Rorippa dictyosperma Carex tasmanica Carex gunniana * Lolium perenne Epilobium billardierianum * Trifolium repens * Cyperus tenelius Isolepis platycarpus * Parentucellia viscosa *Trifolium dubium *Sonchus oleraceus * Petrorhagia nanteuilii Elymus scabrus Deyeuxia quadriseta Dichelachne rara Convolvulus erubescens Ptilotus spathulatus Pimelea humilis Geranium solanderi Arthropodium minus Asperula conferta * Rosa rubiginosa Danthonia caespitosa * Plantago coronopus Danthonia carphoides * Aromus moll is Arthropodium milleflorum Hypoxis glabella Lomandra nana *Briza minor Poa labillardierei Poa hookeri Acaena ovina *Erodium cicutarium Wurmbea dioica *Centaurium erythraea Danthonia pilosa Acaena echinata Juncus spp. Carex gaudichaudiana

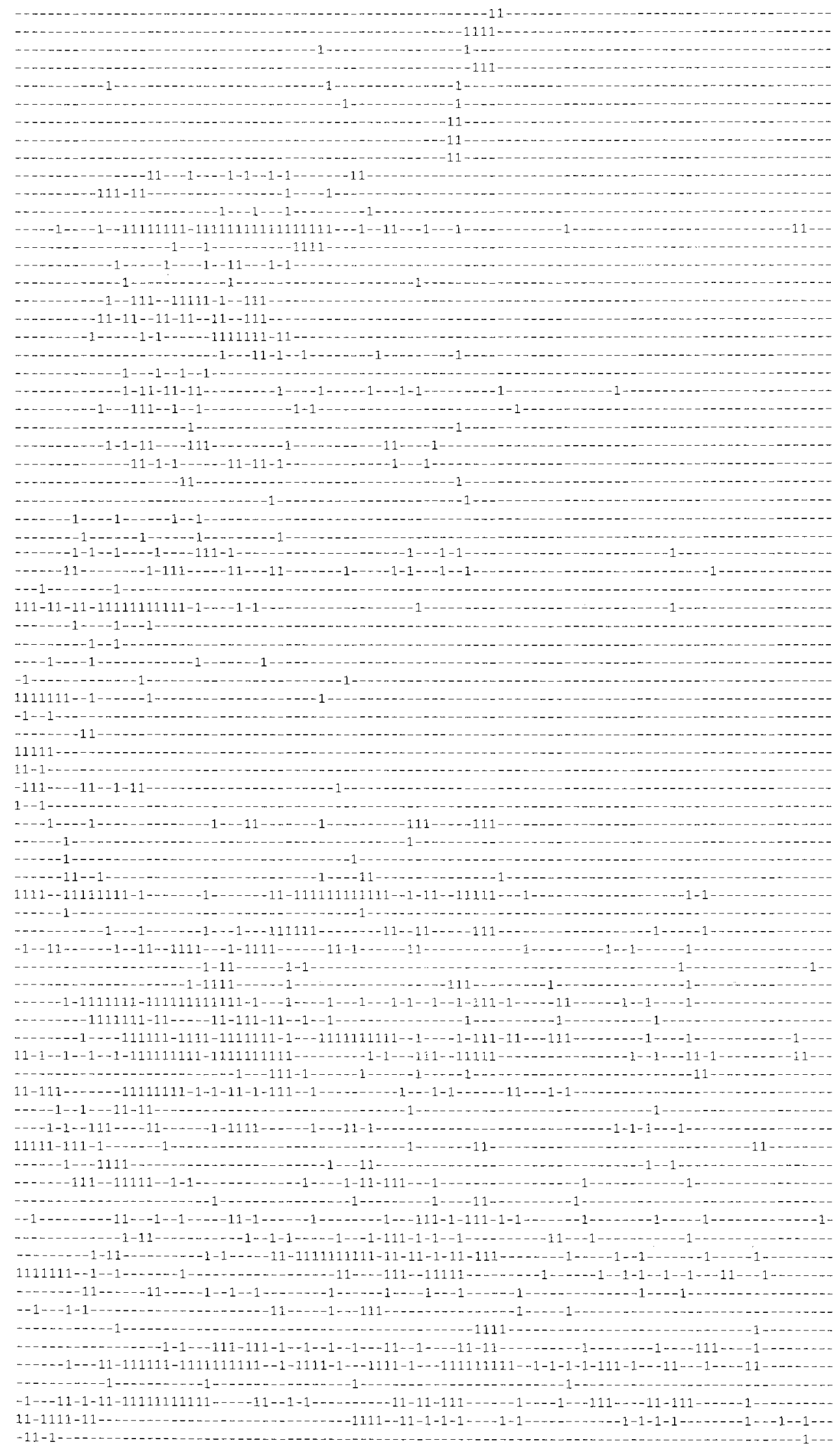


Veronica gracilis * Cirsium vulgare *Trifolium glomeratum * Agrostis capillaris Luzuia spp. Hibbertia riparia Juncus australis Luzula meridionalis * Juncus capitatus * Briza maxima Hibbertia serpyllifolia * Aphanes arvensis * Acetosella vulgaris * Cerastium glomeracum Danthoniz spo. Stipa flavescens Themeda triandra Carex breviculmis Leptorhynchos squamatus Leptorhynchos squal + Schoenus absconditus Dichondra repens Plantago varia Solenogyne gunnit * Aira caryophyliea Danthonia laevis *Hypochoeris radicata Microtis spp. *Moenchia erecta *Vulpia myuros Dianelia revoluta Acaena novae-zelandiae Epilobium hirtigeruin *Taraxacum officinale Epilobium spp. *Anthoxanthum odoratum Juncus subsecundus Juncus buforius ophioglossum lusitanicum Hyalosperma demissum * Polycarpon tetraphylium *Erophila verna Daucus glochidiatus Vittadinia gracilis stackhousia monogyna Pertapogon guadrifidus * Vlex europaeus Lepidosperma gunnit Helichrysum scorpioides Dichopogon strictus Hibbertia prostrata Ranuncuius lappaceus Pultenaea prostrata Eryngium vesiculosum Juncus pauciflorus * Cerastium fontanum Pteridium esculentum Drosera peltata Eucalyptus pauciflora *Leontodon taraxacoides Carex inversa

Astroloma humifusum Lissanthe strigosa Danthonia semiannularis Carex iynx

Pratia pedunculata Cynoglossum suaveolens Pterostylis spp. Centrolepis strigosa Colobanthus curtiseae Poa sieberiana Geranium sessiliflorum scleranthus bifiorus Eucalyptus viminalis Centrolepis aristata Millotia tenuifolia Crassula sieberiana Gnaphalium collinum Pelargonium australe wahlenbergia spp. Solenogyne dominit Hypericum gramineum Acacia dealbata Eursaria spinosa Coprosma quadrifida Poa rodwayi

Ehrharca stipoides Lomandra longifoliä Thelymitra spp.

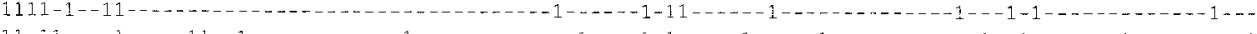

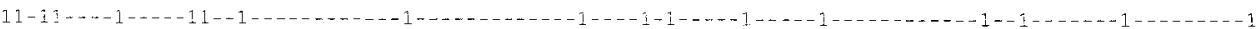

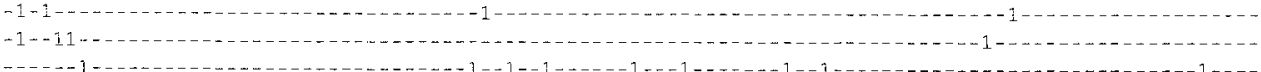

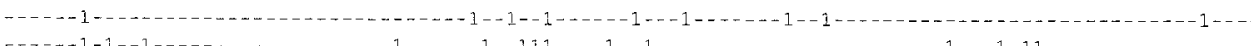
-

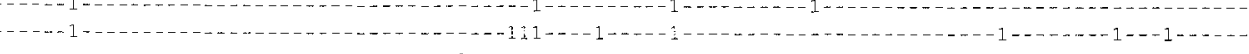
… (n) $1-1-\ldots$

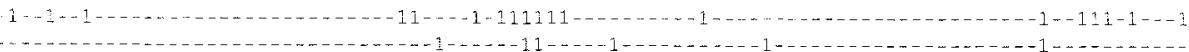
1-1-11-11111111111117111111121-121111:11-1-111111-1111111- 1-11(1) 1111-11-11111111-1111111111-1-11111111-n-2--

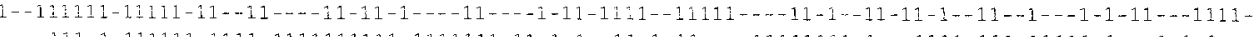
-111-1-111111-1111-111111111-1111111-12-1-1--11-1-11---11i11111-1--11i1-111-11111-1---1-1-11----1--11-111111111-111-111111-1-1111-11--1-1111--11--111-111111-111--1111---1-11111111.11----1 1111111111111111111111111111111111111111111111111111111111111111111111111111111111111111111111111

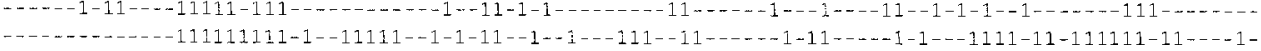
-

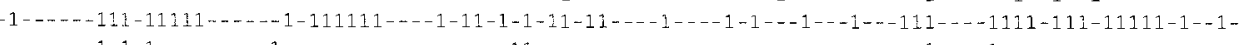
1-1-111-1111111-1-111--1111-1111111111111111111-111111-11--11--1-1111111---1-1--11-

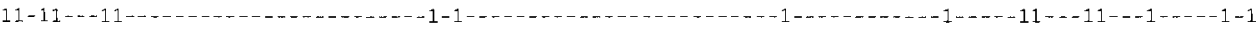
11-11-1

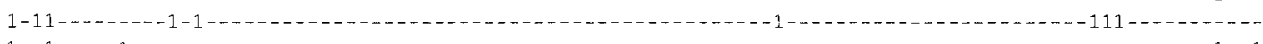
$1-12-1-1-19-19$ $-10-1-0$
-

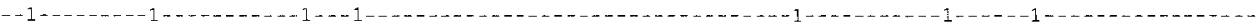
(1) -

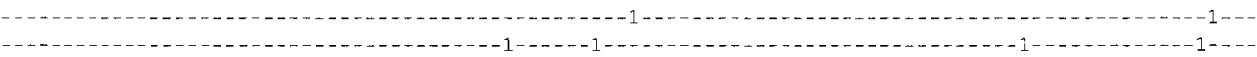
-1-1$11-111-1-1-1-1-1+1-111-111-11111-1-\ldots-111-1-111-1111-11111-11--1$ (1-1-

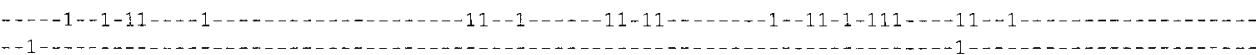
-1

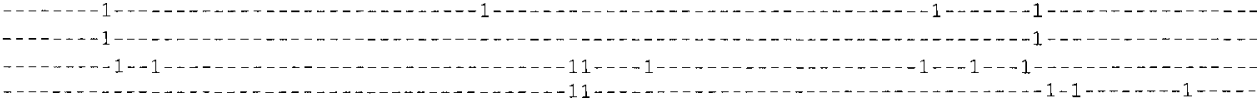
-

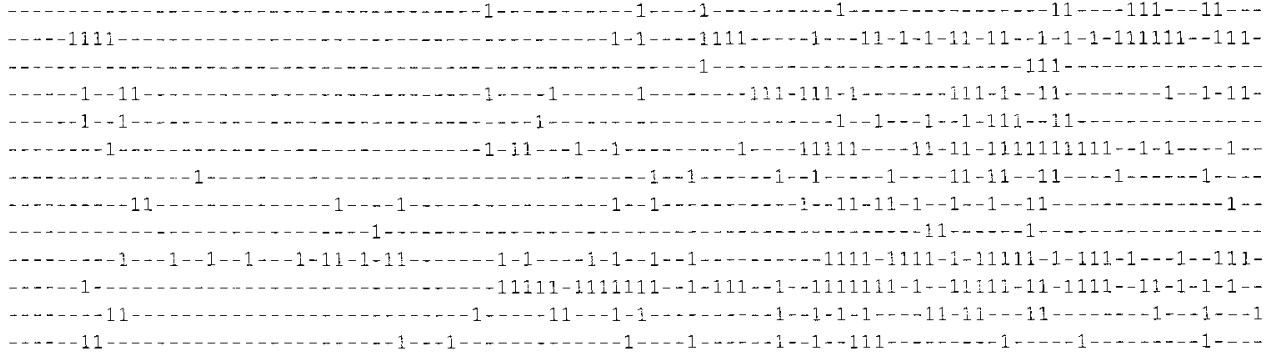


+Hibbertia hirsuta Logfia galiica Corybas spp. + Lepidosperma inops viola hederacea Schoenus apogon Thysanotus patersoni Gonocarpus tetragynus poranthera microphylia Lagenifera stipitata oreomyrtis exiopoda Galium spp.

Hydrocotyle sibthorpioides Microseris lanceolata

Cheilanthes austrotenuifolia Leucopogon coliinus *Anagallis arvensis Sebaea ovata * Galium murale Hydrocotyle callicarpa Cardamine spp. Senecio Iautus veronica calycina +Eucalyptus amygdalina Hypericum japonicum Viola betonicifolia + Lomatia tinctoria Cymbonotus preissianus Acacia mearnsi i

Allocasuarina verticillata Lepidosperma laterale Glycine latrobeana Goodenia lanata Acacia genistifolia Eucalyptus ovata Agrostis venusta Baeckea ramosissima Brachyscome aculeata Ajuga australis

Acrotriche serrulata Bossiaea prostrata opercularia ovata haloragis heterophylla Lagenifera huegeli i

Additional species 68: *Plantago major 11: *uncus articulatus 70: Eleocharis acuta, Mazus pumilio, Dlantago antarctica 196: *Dactylis glomerata 42: Senecio guadridentatus 76: Drosera pygmaea, Leptospermum lanigerum 22: *Rumex crispus 59: *Cardaria draba, *Poa pratensis 48 : Daviesia Ulicifolia 52: Trachymene humilis 49: *Crataegus monogyna 30: *Conyza albida, Isoetopsis graminifolia, *Passiflora cinnabarina 45: Chrysocephalum semipapposum 7: Stipa mollis 28: "Bromus hordeaceus 33: Bulbine glauca, Luzula flaccida 40: Bossiaea cinerea 12: Eterostylis cynocephala 14: *Arctotheca calendula, Pterostylis cucullata 34: Comesperma volubile, Senecio glomeratus 60: Banksia marginata, Chrysocephalum aff.apiculatum 74: Microtis unifolia, stipa pubinodis s4: Rubus parvifolius 85: Wurmbea uniflora 98: Imperata cylindrica 71: Burchardia umbellata, Juncus procerus, Tetratheca procumbens 91 : Cotula reptans, *Erodium botrys 13: +Epacris tasmanica, +Eucalyptus pulchella, Leptospermum scoparium 26: +Bedfordia salicina +Cyathodes pendulosa, Notelaea ligustrina 61: Lythrum hyssopifolium 67: Danthonia racemosa 16: Epacris gunnil, Grevillea australis, Melaleuca gibbosa, Pomaderris pilifera, +Spyridium microphyllum, styphelia adscendens 80: pultenaea pedunculata 62: *Linum trigynum 65: Eriochilus cucullatus 66: Juncus filicaulis 72: +Clematis gentiamoides 83: +Melaleuca pustulata 100: Danthonia setacea, *Reseda luteola 64: Agrostis aemula, Asplenium flabellifolium, Epacris impressa 75: *Cynosurus cristatus 82: Diuris sulphurea, Hydrocotyle callicarpa 101: +ozothamnus scutellifolius 20: Cryptandra amara, Stylidium graminifolium 27: Ozothamns ferrugineus 89: Aphelia pumilio, Calandrinia calyptrata, *Cicendia filiformis, *Sagina apetala 21: Amperea xiphoclada, +Eucalyptus tenuiramis, Hovea Iinearis 5: Acianthus spp., Brachyloma ciliatum, Cotula australis, Gonocarpus micranthus, Hydrocotyle hirta, `Sagina procumbens 41: Ehrharta distichophylla, Eucalyptus globulus, Olearia phlogopappa, olearia ramulosa, Pomaderris elliptica 79: Agrostis parviflora, Baeckea gunniana, Cotula alpina, *Verbascum thapsus, Viola cleistogamoides 88: Hymenanthera dentata

* = incroduced species, + = Tasmanian endemic species 
TABLE 4

Mean densities of Schoenus absconditus* in varying cover classes

\begin{tabular}{|c|c|c|c|c|c|c|c|c|}
\hline \multirow[t]{2}{*}{ Type of cover } & \multicolumn{7}{|c|}{ Cover class ${ }^{\dagger}$} & \multirow[t]{2}{*}{$\mathrm{H}^{\ddagger}$} \\
\hline & 0 & 1 & 2 & 3 & 4 & 5 & 6 & \\
\hline grass & - & 332 & 170 & 182 & 92 & - & 185 & 12.149 \\
\hline herb & - & - & 287 & 152 & 215 & - & - & 7.88 \\
\hline exorics & 83 & 196 & 195 & 220 & - & - & - & 4.91 \\
\hline bare ground & - & 159 & 220 & 262 & 238 & 184 & 95 & 21.195 \\
\hline rock & 163 & 84 & - & - & - & 395 & 237 & 21.445 \\
\hline litter & 193 & 141 & 313 & 262 & - & 123 & - & $11.50 \leqq$ \\
\hline
\end{tabular}

* Mean densities per square metre (Muelier-Dombois \& Ellenberg 1974)

$\dagger 0=0 \%, 1=1 \%, 2=2-5 \%, 3=6-25 \%, 4=26-50 \%, 5=51-75 \%, 6=76-100 \%$

$\ddagger \mathrm{H}$ values and significance levels for the Kruskal-Wallis One-Way Analysis of Variance by Ranks $(\$=\mathrm{P}<0.05$,

$\mathrm{S}=\mathrm{P}<0.001$ )

and generally consist of less than 100 individuals, making them highly vulnerable to localised extinction through the inadvertent or deliberate use of a plough or grader. Such an extinction occurred in the municipality of Kingborough in the course of road preparation for a subdivision. During the lase five years, two populations have become extinct. This is a loss of more than $10 \%$ of the known populations every decade - a rate which could lead to the endangerment or extinction of the species within 50 years. The species is best considered to be vulnerable to extinction and should be reinstated to the state list of threatened flora (Flora Advisory Committee 1994).

Carex tasmanica does not place high demands on managers (Gilfedder 1991). The avoidance of deep scraping, cartle grazing and mowing, and the maintenance of the other forms of disturbance currently employed are all that is required. It would be highly desirable to ensure that at least one large population was within a secure reserve. Areas that might be suitable for secure reservation include city parks and some private land. There are areas of private grassland with this species that, if purchased and maintained under present management regimes, would also increase the security of lowland temperate grassland and other rare and threatened species (Kirkpatrick 1994).

\section{ACKNOWLEDGEMENTS}

Alex Buchanan, Stephen Harris, Mark Neyland, Andy North and Andrew Zacharek provided some site records for C. tasmanica. Dr Winifred Curtis provided taxonomic assistance. Dennis Morris and Alex Buchanan helped with species identification. The Hobart Cicy Council, and in particular John Rankin, co-operated with experiments on the Queens Domain. Gian Walthur helped with some data collection. Dr G. van der Geer drew some of the figures.

This project was supported by grants from the Worldwide Fund for Nature (Australia) and the Endangered Species Program of the Australian Nature Conservation Agency (ANCA).
TABLE 5

Mean and standard error of Carex tasmanica and other lifeform groups under different management regimes*

\begin{tabular}{|c|c|c|}
\hline & $1991^{\dagger}$ & $1.995^{\dagger}$ \\
\hline \multicolumn{3}{|c|}{ Carex tasmanica individuals $/ \mathrm{m}^{2}$} \\
\hline woodchips & $137.6 \pm 37.8$ & $156.3 \pm 39.2$ \\
\hline spray/burn & $96.9 \pm 33.9$ & $350.0 \pm 110.0$ \\
\hline mown & $92.5 \pm 28.1$ & $147.5 \pm 41.7$ \\
\hline \multicolumn{3}{|c|}{ Carex tasmanica clumps $/ \mathrm{m}^{2}$} \\
\hline woodchips & $8.73 \pm 1.91$ & $16.85 \pm 2.96$ \\
\hline spray/burn & $10.27 \pm 3.56$ & $9.82 \pm 2.83$ \\
\hline mown & $19.38 \pm 4.61$ & $18.13 \pm 4.61$ \\
\hline \multicolumn{3}{|c|}{ Carex tasmanica germinates $/ \mathrm{m}^{2}$} \\
\hline woodchips & $15.62 \pm 9.60$ & $6.87 \pm 4.41$ \\
\hline spray/burn & $4.91 \pm 3.35$ & $3.12 \pm 1.43$ \\
\hline mown & 0 & 0 \\
\hline \multicolumn{3}{|c|}{ Carex tasmanica percentage cover } \\
\hline woodchips & $6.70 \pm 1.65$ & $5.90 \pm 1.42$ \\
\hline spray/burn & $4.71 \pm 1.56$ & $8.96 \pm 2.67$ \\
\hline mown & $2.60 \pm 1.09$ & $5.30 \pm 0.92$ \\
\hline \multicolumn{3}{|c|}{ Percentage cover of exotic herbs } \\
\hline woodchips & $11.00 \pm 2.73$ & $17.40 \pm 4.04$ \\
\hline spray/burn & $6.43 \pm 1.25$ & $11.71 \pm 2.049$ \\
\hline mown & $31.20 \pm 3.52$ & $31.50 \pm 3.49$ \\
\hline \multicolumn{3}{|c|}{ Percentage cover of exotic rosette herbs } \\
\hline woodchips & $3.60 \pm 1.82$ & $5.70 \pm 2.59$ \\
\hline spray/burn & $3.14 \pm 0.71$ & $7.86 \pm 1.12 \$$ \\
\hline mown & $22.80 \pm 2.00$ & $27.80 \pm 2.72$ \\
\hline \multicolumn{3}{|c|}{ Percentage cover of exotic grasseș } \\
\hline woodchips & $18.20 \pm 2.33$ & $33.80 \pm 5.47^{\ddagger}$ \\
\hline spray/burn & $10.04 \pm 3.28$ & $29.79 \pm 4.94 \$$ \\
\hline mown & $24.56 \pm 3.66$ & $36.53 \pm 3.22 \$$ \\
\hline
\end{tabular}

* Density, cover and number of germinants, and herb, rose tte herb and exotic grass cover per square metre.

+ Significance levels shown for the Mann-Whitney U Test $(\ddagger \mathrm{P}<0.05, \S=\mathrm{P}<0.01,9=\mathrm{P}<0.001)$. 


\section{REFERENCES}

BRIGGS, J.D. \& LEIGH, J.H., 1988. RARE OR THREATENED AUSTRALIAN PLANTS. Spec. Publ. 14. Australian National Parks \& Wildlife Service.

BuChanan, A.M., 1995. A census of the vascular plants of Tasmania. Tasm. Herb. Occ. Publ. 5.

BUSBY, J.R., 1988. Potential implications of climatic change on Australia's flora and fauna. In Pearman, G.I. (Ed.): GREENHOUSE PLANNING FOR CLIMATE CHANGE. CSIRO, Melbourne.

CURTIS, W.M. \& MORRIS, D.I., 1994. THE STUDENTS FLORA OF TASMANIA. Part 4B. Angiospermae: Alisrnataceae to Burmanniaceae. St David's Park Publishing, Hobart.

Endangered Flora Network, 1993: THREATENED AUSTRALIAN FLORA. Australian Nature Conservation Agency, Canberra.

Flora Advisory COMMITTEe, 1994: NATIVE HIGHER PLANT TAXA WHICH ARE RARE OR THREATENED IN TASMANIA. Parks \& Wildlife Service, Tasmania.

Gilfedder, L.., 1991. Carex tasmanica Flora Recovery Plan: Management Phase. Department of Parks, Wildlife \& Heritage, Hobart.

Gilfedder, L. \& Kirkpatrick, J.B., 1994. Climate, grazing and disturbance and the population dynamics of Leucochrysum albicans at Ross, Tasmania. Aust. J. Bot. 42: 417-430.

GUllan, P.K., ChEAL, D.C. \& WAlsh, N.G., 1990: RARE OR
THREATENED PLANTS IN VICTORIA. Dep. Conservation \& Environment, Victoria.

HILL, M.O., 1979. TWINSPAN: A FORTRAN program for arranging multivariate data in an ordered two-way table by classification of the individual and attributes. Cornell University, New York.

HNATIUK, R., 1990: CENSUS OF AUSTRALIAN VASCULAR PLANTS. Aust. Flord \&Fauna Ser. 11. Australian Government Printing Service, Canberra.

Kirkpatrick, J.B., 1994. Tasmania. In McDougall, K. \& Kirkpatrick, J.B. (Eds.): CONSERVATION OF LOWLAND NATIVE GRASSLANDS IN SOUTHEASTERN AUSTRALIA. World Wide Fund for Nature, Australia, Sydney: 129-157.

Mueller-Dombois, D. \& Ellenerg, H., 1974: AIMS AND METHODS OF VEGETATION ECOLOGY. Wiley International, New York.

SiEgEL, S., 1956: NONPARAMETRIC STATISTICS FOR THE BEHAVIORAL SCIENCES. McGraw-Hill Kogakusha L.td, Japan.

(accepted 18 December 1995) 